\title{
OPEN Biomass potential of novel interspecific and intergeneric hybrids of Saccharum grown in sub-tropical climates
}

\author{
Mintu Ram Meena ${ }^{1 凶}$, Ravinder Kumar ${ }^{1}, K^{2}$ aruppaiyan Ramaiyan ${ }^{1,2}$, Manohar Lal Chhabra $^{1}$, \\ Arun Kumar Raja ${ }^{2}$, Mohanraj Krishnasamy ${ }^{2}$, Neeraj Kulshreshtha ${ }^{1}$, Shashi Kant Pandey ${ }^{1}$ \& \\ Bakshi Ram ${ }^{1,2}$
}

Sugarcane-derived biomass is a promising source of renewable energy to meet the growing demands for biofuel. Currently, modern sugarcane cultivars are unable to provide enough biomass due to their narrow genetic base and susceptibility to abiotic and biotic stresses. We have evaluated total of 23 hybrids derived from diverse genetic backgrounds of different Saccharum spp. and allied genera, one inbred and compared with commercial checks. Intergeneric hybrids (IGHs) KGS 99-100 and GU 04-432, produced significantly higher biomass $\left(43.37 \mathrm{tha}^{-1}\right.$ and $35.24 \mathrm{tha}^{-1}$, respectively) than commercial sugarcane have genes derived from Erianthus arundinaceus. Interspecific hybrids (ISHs) GU 07-3704 and 99-489, also produced significantly higher amounts of biomass $\left(37.24 \mathrm{tha}^{-1}\right.$ and $33.25 \mathrm{t} \mathrm{ha}^{-1}$, respectively) than commercial checks have genes from S. officinarum and S. spontaneum backgrounds. ISHs recorded significantly higher biomass yield, number of stalks and total dry matter percentage whereas, IGH group recorded significantly higher fibre percent. Furthermore, the clones resistant to red rot and sugarcane borers were identified. The estimated energy value for seven hybrid clones was found to be very high. Cluster analysis of genetic traits revealed two major clusters in traits improving biomass. Our study has revealed that the genetic diversity present in these hybrids could be used for improving biomass production and tolerance to abiotic and biotic stresses in cultivated sugarcanes.

The substantial use of fossil fuels in the twenty-first century has resulted in a huge upsurge in atmospheric $\mathrm{CO}_{2}$ levels leading to global warming and other environmental effects. In addition, sudden surges in crude oil prices in the international market are driving economies to develop new sources of environmentally friendly and renewable energy sources. In a recent review, Fawzy et al. $(2020)^{1}$ have lately evaluated several mitigation strategies to reduce $\mathrm{CO}_{2}$ emissions by using renewable energy sources, fuel switching, efficiency gains, nuclear power, and carbon capture storage and utilization methods. Amongst these strategies, plant biomass-derived biofuels hold great potential as replacements for fossil fuels to reduce greenhouse gas emissions.

Sugarcane (Saccharum spp.) is an important industrial crop grown in over 80 tropical and sub-tropical countries. Globally, $\sim 26.9$ million hectares of land are used for sugarcane cultivation; these produce 1.9 billion tonnes of fresh sugarcane, roughly translating to a yield of $\sim 70.9$ tonnes/hectare ${ }^{2}$. Sugarcane is a C4 plant and so has a very efficient photosynthesis process and an exceptionally high biomass accumulating capacity in the form of carbohydrates; it also has a much higher energy input/output ratio than most other crops ${ }^{3,4}$. Sugarcane-based biomass, therefore, can be a low-cost energy production system ${ }^{5}$ and a versatile source of renewable energy as ratooning allows the growth and harvest of four or five crops without replanting ${ }^{6}$.

One of the major limitations in using plant biomass for combustion/pyrolysis in energy production, is the production of toxic nitrogen oxides; nonetheless, a study by Osman $(2020)^{7}$ has demonstrated that coupling the DeNOx catalyst with urea to construct an in-situ selective catalytic reduction (SCR) $\mathrm{NH}_{3}$-SCR system during the combustion process can significantly reduce nitrogen oxide emissions.

In order to reduce greenhouse gases (GHGs) emissions, large scale deployments of negative emissions technologies (NETs; i.e. technologies that result in the net removal of $\mathrm{CO}_{2} / \mathrm{GHGs}$ from the atmosphere) are required ${ }^{8}$. The major forms of NET currently in use include technologies for bioenergy carbon capture and storage, and

${ }^{1}$ ICAR-Sugarcane Breeding Institute, Regional Centre, Karnal, India. ${ }^{2}$ ICAR-Sugarcane Breeding Institute, Coimbatore, India. ${ }^{\boxplus}$ email: mintu_uas@yahoo.co.in 
biochar and soil carbon sequestration ${ }^{1}$. Most of these technologies, however, are currently only in the demonstration stages, and large-scale efforts are still required to offset the current levels of $\mathrm{CO}_{2}$ emissions produced by humans. Since sugarcane is a high biomass producing crop, it could be used to convert $\mathrm{CO}_{2}$ into soil carbon; one study shows that sugarcane plantations can convert more $\mathrm{CO}_{2}$ into soil carbon than matured or secondary forests ${ }^{9}$. It has been found that sugarcane yields in Australia increased by $8 \%$ and $4 \%$ with weak climate change and moderate climate change, respectively, but were reduced by $10 \%$ with strong climate change ${ }^{10}$. Sugarcane based biomass (bioenergy) is a low cost energy production system ${ }^{5}$ and a versatile source of renewable energy as it allows four to five times harvest of ratoon without replanting ${ }^{6}$.

To date, sugarcane is among the most efficient crops in the world along with other $\mathrm{C}_{4}$ grasses when it comes to conversion of solar energy into stored chemical energy and biomass accumulation ${ }^{11}$. It has been estimated that more than $700 \mathrm{Mha}$ of land being used to grow cereal crops produced a total of only $2400 \mathrm{mt}^{-1} \mathrm{ear}^{-1}$ of biomass, whereas only 21 Mha of sugarcane crops alone produced $1750 \mathrm{mt} \mathrm{year}^{-1}$ of biomass $^{12}$. Therefore, sugarcane may provide a vital solution to many environmental problems without reducing economic benefits at the global level.

Conventionally, in the sugar industry, the "bagasse" that remains after juice extraction through crushing is an important by-product used to generate electricity and produce fertilizers ${ }^{13}$. More recently, it has been used for biofuel production ${ }^{14,15}$. However, the production cost for bioconversion of sugarcane biomass into biofuel is still considered to be relatively high, which makes it difficult to commercialize on a large scale ${ }^{16}$. Therefore, it is essential to develop improved sugarcane varieties with high biomass yield and fibre content, which also have better biomass degradability; in addition, we also need better enzyme digestion technologies to maximize the efficiency of conversion of sugarcane biomass into biofuel ${ }^{17}$.

Brazil is the first country to have successfully launched an ethanol-based fuel program (ProAlcooL), which produces alcohol on a large scale from sugarcane ${ }^{18}$; in 2014, Brazil produced around 23.4 billion litres of ethanol from sugarcane biomass (Renewable Fuel Association, 2015). However, India has also successfully exploited the energy potential of sugarcane to produce ethanol and electricity ${ }^{19}$. To enhance Indian's energy security, the Government of India (GoI) aimed to increase ethanol blending percentages in gasoline fuels from 5 to $20 \%$ by 2017.

Since usage of biofuels now plays a significant role in drafting the energy policies of many countries, several studies have shown that producing biomass for use as biofuels can be significantly increased ${ }^{20}$. Unfortunately, at present, the cane varieties cultivated in India have only 13-15\% fibre, and the development of high biomass producing cultivars has enormous potential to meet the energy demand in the country ${ }^{21}$.

In India, sugarcane is grown under both tropical and subtropical areas. The sub-tropical region faces climatic vagaries throughout the year, such as flooding, extreme winter and summer temperatures, drought, and salinity, all of which are major constraints for crop production. Therefore, in order to be able to grow high biomass producing sugarcane crops under subtropical regions, we need to develop high biomass-type clones which are also tolerant to several different types of environmental stresses ${ }^{22}$.

There is tremendous genetic variation found within the Saccharum species and allied genera of Miscanthus, and Erianthus species that can be exploited for high biomass and fibre in sugarcane breeding programs ${ }^{23}$. However, in the recent past, although the genetic diversity of $S$. officinarum has been exploited towards this end, the genetic diversities of S. spontaneum ${ }^{24}$, S. robustum and other allied genera have not been explored ${ }^{25}$.

The ICAR-Sugarcane Breeding Institute, Coimbatore, has been working to generate intergeneric (IGH) and interspecific (ISH) hybrids of sugarcane with high biomass production potential using S. spontaneum, S. robustum, S. barberi, and Erianthus arundinaceus ${ }^{26}$. In this study, we evaluate the potential of IGHs and ISHs and we have generated as potential energy and fuel producers.

\section{Results}

A high degree of variation among the clones under study (Table 1) for all the traits in both the years was observed. The interaction term for year and clone (year $\times$ clone) identity was significant for all traits except numbers of millable canes (NMC), which indicates that the performance of the clones varied between the two years of growth. Further, it was assumed that the interaction term genotypes $x$ environment $(G \times E)$ plays a significant role in the performance of these hybrids over several years. However, the interaction between year and replication was found to be non-significant, indicating that replications over different years do not have a significant impact on the traits studied. The results of the two-way analysis of variance (ANOVA) for the eight biomass related traits for two years are shown in Table 2.

Biomass production and traits affecting biomass production. The characteristics of ISHs and IGHs were compared with either commercial sugarcane or population means to identify clones with better-performing traits in biomass production. Out of the 28 clones evaluated, five ISHs and two IGHs recorded significantly higher dry biomass yields as compared to the population mean of $29.03 \mathrm{t} \mathrm{ha}^{-1}$. Eight ISHs-2004-186 (38.34 t $\left.\mathrm{ha}^{-1}\right)$, GU 07-3704 (37.24 t ha-1), KGS 2004-13 (35.43 $\left.\mathrm{t} \mathrm{ha}^{-1}\right)$, 99-489 (33.25 t ha-1), KGS 2004-60 (32.93 $\left.\mathrm{t} \mathrm{ha}^{-1}\right)$, GU 07-3849 (31.83 $\left.\mathrm{tha}^{-1}\right)$, 99-488 (31.25 $\left.\mathrm{tha}^{-1}\right)$, and 99-81 (31.15 $\left.\mathrm{tha}^{-1}\right)$-and two IGHs, namely, KGS 99-100 (43.37 t ha ${ }^{-1}$ ) and GU 04-432 (35.24 $\mathrm{t} \mathrm{ha}^{-1}$ ) were significantly superior to the best commercial standard, Co $0238\left(27.88 \mathrm{t} \mathrm{ha}^{-1}\right)$, in dry biomass yields (Fig. 1). The estimated value of dry biomass produced ranged from 18.07-43.37 $\mathrm{t} \mathrm{ha}^{-1}$ for all the studied clones. The lowest dry biomass yield $\left(20.76 \mathrm{t} \mathrm{ha}^{-1}\right)$ was recorded by the clone GU 04-431. The overall means for dry biomass yield for all ISHs and IGHs were $30.37 \mathrm{t} \mathrm{ha}^{-1}$ and $28.75 \mathrm{tha}^{-1}$, respectively, while that of commercial varieties was $24.81 \mathrm{t} \mathrm{ha}^{-127}$. The highest dry biomass yielding clone was KGS 99-100 (43.37 tha-1), a hybrid clone between a commercial cultivar and E. arundinaceus.

Total dry matter (DM) accumulation ranged from $19.78 \%$ (GU 04-432) to $40.42 \%$ (GU07-3730). Four of the ISHs-GU 07-3730 (40.42\%), GU 07-3784 (37.35\%), KGS 2004-60 (35.80\%), and GU07-3764 (32.53\%)-accumulated significantly higher percentages of DM as compared to commercial cultivars at the time of harvest ${ }^{28}$. In 


\begin{tabular}{|c|c|c|c|c|}
\hline \multirow[b]{2}{*}{ S.No } & \multirow[b]{2}{*}{ Clone name } & \multirow{2}{*}{$\begin{array}{l}\text { Parentage (S. officinarum, S. spontaneum, and S. } \\
\text { robustum) }\end{array}$} & \multicolumn{2}{|l|}{ Species } \\
\hline & & & Female & Male \\
\hline 1 & GU 092-410 & IND 90-776 X Co 775 & S. spontaneum & Commercial cane \\
\hline 2 & 99-81 & Co 85002 X (PIO 88-96 x SIP-54) & Commercial cane & S. officinarum \\
\hline 3 & $99-132$ & Co 86002 x (PIO 88-1715 X IND-82-319) & Commercial cane & $\begin{array}{l}\text { S. officinarum } \\
\text { S. spontaneum }\end{array}$ \\
\hline 4 & $99-438$ & PIO 88-1809 X (PIO 88-100 x SIP-93-8) & S. officinarum & S. officinarum \\
\hline 5 & $99-488$ & PIO 88-110 X ( PIO 90-202 x SIP 32) & S. officinarum & S. officinarum \\
\hline 6 & $99-489$ & PIO 88-110 X (PIO 90-202 x SIP 32) & S. officinarum & S. officinarum \\
\hline 7 & KGS 2004-13 & Co 86002 X 97-244 (Pathri x Co 87268) & Commercial cane & S. barberi and S. sinense \\
\hline 8 & KGS 2004-48 & 97-121 (Kansor x BC 82-175) X Co 90018 & S. barberi and S. sinense & Commercial cane \\
\hline 9 & KGS 2004-60 & 97-121 (Kansor x BC 82-175) X Co 775 & S. barberi and S. sinense & Commercial cane \\
\hline 10 & KGS 2004-72 & 97-121 (Kansor x BC 82-175) X Co 775 & S. barberi and S. sinense & Commercial cane \\
\hline 11 & KGS 2004-90 & Co 86002 X 97-244 ( Pathri x Co 87268) & Commercial cane & S. barberi and S. sinense \\
\hline 12 & KGS 2004-186 & Co 88028 X 97-130 (Kansor x BC 82-175) & Commercial cane & S. barberi and S. sinense \\
\hline 13 & GU 07-3704 & PIO-88-110 X IND 00-1061 & S. officinarum & S. spontaneum \\
\hline 14 & GU 07-3730 & PIO-88-110 X IND 00-1061 & S. officinarum & S. spontaneum \\
\hline 15 & GU 07-3764 & PIO-88-110 X IND 00-1061 & S. officinarum & S. spontaneum \\
\hline 16 & GU 07-3784 & PIO-88-110 X IND 00-1061 & S. officinarum & S. spontaneum \\
\hline 17 & GU 07-3849 & PIO-88-1703 X IND 00-1058 & S. officinarum & S. spontaneum \\
\hline 18 & GU 98-1395 & CoC 671 X IG 91-1100 & Commercial cane & Erinathus arundinaceus \\
\hline 19 & KGS 99-100 & Co 7201 X IK 76-76 & Commercial cane & Erinathus arundinaceus \\
\hline 20 & KGS 99-104 & Co 7201 X IK 76-76 & Commercial cane & Erinathus arundinaceus \\
\hline 21 & KGS 99-109 & Co 7201 X IK 76-76 & Commercial cane & Erinathus arundinaceus \\
\hline 22 & GU 04-431 & PIR 98-635 X IK 76-91 & S. robustum & Erinathus arundinaceus \\
\hline 23 & GU 04-432 & PIR 98-635 X IK 76-91 & S. robustum & Erinathus arundinaceus \\
\hline 24 & Co 0238 & CoLk 8201 X Co 775 & Commercial cane & Commercial cane \\
\hline 25 & CoJ 64 & Co 976 X Co 617 & Commercial cane & Commercial cane \\
\hline 26 & $\operatorname{Cos} 767$ & Co 419 X Co 319 & Commercial cane & Commercial cane \\
\hline 27 & $\operatorname{CoS} 8436$ & MS 68/47 X Co 1148 & Commercial cane & Commercial cane \\
\hline 28 & $1148-54-242-2$ & Co 1148 (Selfing) & Commercial cane & \\
\hline
\end{tabular}

Table 1. Parentage of hybrid clones used in this study (S. no 1 to 17 are ISH clones, S.nos. 18 to 23 are IGH clones, 24 to 27 are commercial checks and, S. no. 28 is an inbred clone).

\begin{tabular}{|c|c|c|c|c|c|c|c|c|c|c|}
\hline \multirow[b]{2}{*}{ Source } & \multicolumn{8}{|c|}{ F-ratio and significance } & \multirow[b]{2}{*}{ Fibre\% } & \multirow[b]{2}{*}{ DBM } \\
\hline & Df & SCW & Cane brix & Juice brix & NMC & TDM & DM & FB & & \\
\hline Rep & 1 & $3.666 \mathrm{~ns}$ & $0.315 \mathrm{~ns}$ & $3.202 \mathrm{~ns}$ & $0.032 \mathrm{~ns}$ & $1.258 \mathrm{~ns}$ & $9.567^{* *}$ & $0.000 \mathrm{~ns}$ & $11.86^{* \star}$ & $9.54^{* *}$ \\
\hline Year & 1 & $21.159^{* * *}$ & $0.306 \mathrm{~ns}$ & $26.328^{* * *}$ & $0.802 \mathrm{~ns}$ & $189.649^{* * *}$ & $10.755^{\star *}$ & $49.918^{* * *}$ & 0.00 & $10.87^{* *}$ \\
\hline Year*Rep & 1 & $0.466 \mathrm{~ns}$ & $2.816 \mathrm{~ns}$ & $0.192 \mathrm{~ns}$ & $0.011 \mathrm{~ns}$ & $1.243 \mathrm{~ns}$ & $0.294 \mathrm{~ns}$ & $0.722 \mathrm{~ns}$ & 1.166 & $0.318 \mathrm{~ns}$ \\
\hline Clone & 27 & $85.867^{* * *}$ & $37.955 \mathrm{~ns}$ & $8.856^{* * *}$ & $34.439^{* * *}$ & $15.123^{* * *}$ & $52.531^{* * *}$ & $91.942^{* * *}$ & $10.95^{\star * *}$ & $52.70^{* * *}$ \\
\hline Year ${ }^{\star}$ Clone & 27 & $2.492^{* *}$ & $0.200^{* * *}$ & $4.031^{* * *}$ & $0.339 \mathrm{~ns}$ & $11.273^{* * *}$ & $2.379^{* *}$ & $3.019^{* * *}$ & $7.06^{* * *}$ & $2.38^{* *}$ \\
\hline Error & 54 & & & & & & & & & \\
\hline C. Total & 111 & & & & & & & & & \\
\hline
\end{tabular}

Table 2. Results of the two-way analysis (F-ratio) showing the effects of genotypes and year on the different traits of sugarcane clones (SCW: single cane weight, NMC: number of millable canes, TDM: total dry matter, DM: dry matter, FB: fresh biomass). Level of significance: ${ }^{* *},{ }^{* *},{ }^{\star}$ and ns indicate significance at $\mathrm{P}<0.001$, $\mathrm{P}<0.01, \mathrm{P}<0.05$, and non-significance, respectively.

energy cane, dry biomass yield is of primary importance, with percentage production of fibre, DM, and NMC also being important traits.

The mean fibre production in the IGHs and ISHs was $16.45 \%$, and ranged from $12.30 \%(99-438)$ to 21.15\% (GU04-432). The best fibre producer amongst the standard commercial canes was CoS 767 (15.84\%). Seven ISHs-2004-13 (19.77\%), GU07-3730 (18.67\%), KGS 2004-72 (18.15\%), 99-488 (18.02\%), GU 94-410 (17.78\%), 2004-186 (17.66\%) and GU 07-3784 (17.83\%)—and three IGHs, namely, GU04-432 (21.15\%), KGS 99-109 (19.68\%), and KGS 99-104 (17.84\%) had significantly higher fibre percentages as compared to the best 


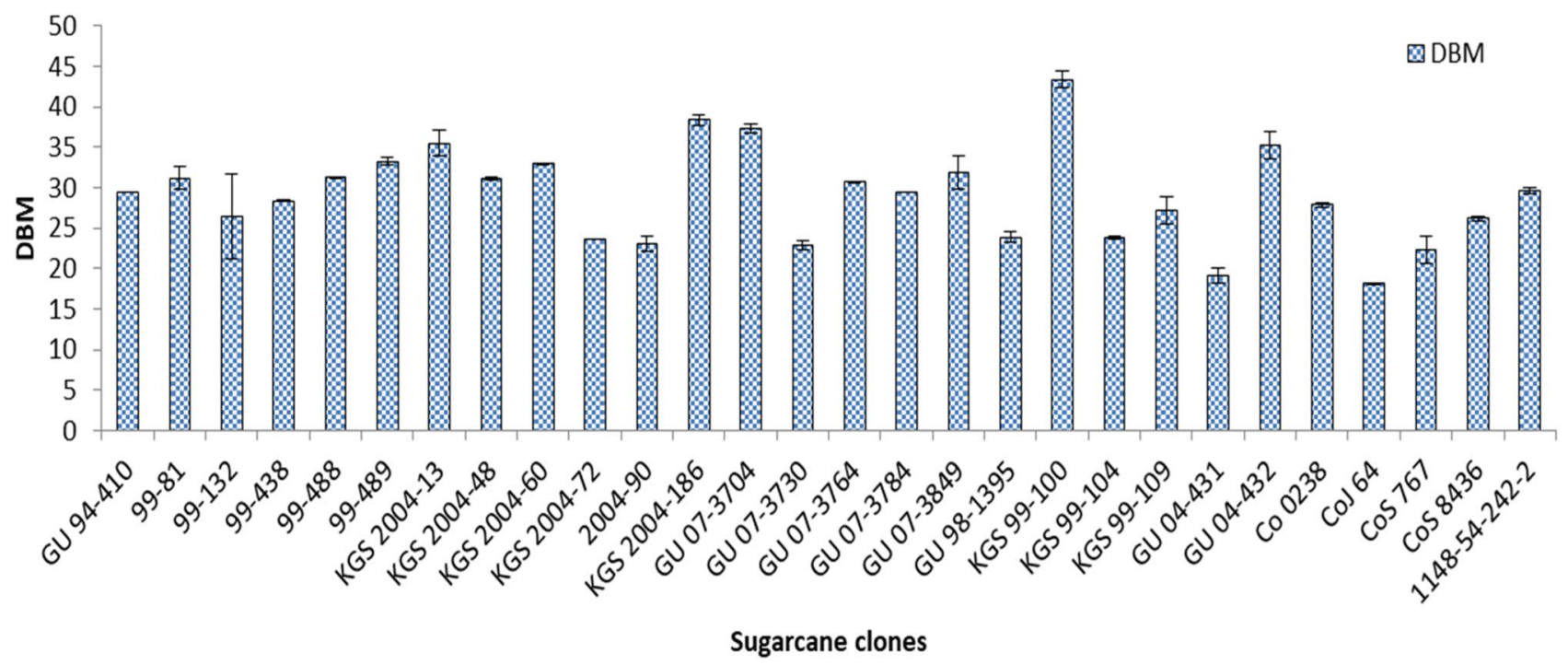

Figure 1. Dry biomass potential (DBM ( $\mathrm{t} / \mathrm{ha})$ ) of interspecific (ISH), intergeneric (IGH), and commercial hybrids of sugarcane.

commercial check. In overall experiment, ISHs group have recorded significantly higher biomass yield, number of stalks, and total dry matter percentage compared to other group whereas, IGHs group have recorded significantly higher fibre percent than ISHs (Table 3).

Cane growth and quality parameters. None of the IGHs and ISHs performed better than the commercial cultivars with respect to juice quality traits such as Brix\% in juice, sucrose \% in juice and purity\% (Table 3). However, six ISHs-KGS 2004-72 (18.80\%), 99-488 (18.70\%), KGS 2004-48 (18.63\%), KGS 2004-60 (18.55\%), GU 07-3764 (18.5\%) and GU 94-410 (18.53\%) were at par with regard to juice quality (Brix\% in juice) with the best commercial standard cultivar Co $0238(20.25 \%)$ at $10^{\text {th }}$-month crop stage. Among these hybrids, two ISHs, 99-488 and KGS 2004-60 had 18.70\% and 18.55\% juice brix, and $31.25 \mathrm{t} \mathrm{ha}^{-1}, 32.93 \mathrm{tha} \mathrm{h}^{-1}$ dry biomass yield, respectively; therefore, these can be used as dual-purpose crops for sugar as well as biofuel production ${ }^{29}$. The overall mean for numbers of stalks per ha was significantly higher in one IGH, KGS 99-109 (1.07 lakh ha $\left.{ }^{-1}\right)$, and five ISHs-GU07-3849 (1.59 lakh ha ${ }^{-1}$ ), GU07-3704 (1.38 lakh ha ${ }^{-1}$ ), GU07-3730 (1.25 lakh ha $\left.{ }^{-1}\right)$, GU07-3764 (1.03 lakh ha $\left.{ }^{-1}\right)$, GU07-3784 (1.20 lakh ha $\left.{ }^{-1}\right)$, as compared to the population mean $\left(0.85 \mathrm{lakh} \mathrm{ha}^{-1}\right)$ and that of the best commercial cultivar $\left(0.80 \mathrm{lakh} \mathrm{ha}^{-1}\right)$. Single cane weight (SCW) of three ISH clones-GU 94-410 $(1.58 \mathrm{~kg})$, KGS 2004-48 (2.25 kg), and KGS 2004-186 (1.74 kg) - and two IGH clones, namely, KGS 99-100 $(1.39 \mathrm{~kg})$ and GU $04-432(1.99 \mathrm{~kg})$, was significantly higher than the population mean $(1.16 \mathrm{~kg})$.

Winter sprouting index (WSI). Three ISHs and one IGHs had significantly higher WSIs than the population mean and that of the best commercial check CoS 767. Out of these, one IGH clone, KGS 99-109, had the highest WSI of 4.52. Five ISHs-GU 07-3704 (3.43), GU 07-3730 (3.71), GU 07-3764 (2.3), GU 07-3784 (2.7), and GU 07-3849 (2.3) had significantly higher WSIs than the best standard CoS 767 (1.47) for WSI (see Supplementary Fig. S1).

Energy value. Based on the analysis of means (ANOM), the clones 99-489, KGS 2004-13, KGS 2004-60, KGS 2004-186, GU 07-3704, KGS 99-100, and GU 04-432 were identified as having significantly higher energy potentials than the overall mean $(461.61 \mathrm{Gj} / \mathrm{ha} /$ year $)$ and the upper decision line $(514.1 \mathrm{Gj} / \mathrm{ha} /$ year $)$. The clones KGS 2004-72, 2004-90, GU 07-3730, GU 98-1395, KGS 99-104, GU 04-431, CoJ 64 and CoS 767 recorded significantly lower energy potentials than the overall mean and lower decision line. However, ten ISH clones, one IGH clone and three commercial canes have energy potentials at par with the population mean. Hence, these mentioned hybrids clones might be a good source of potential biomass energy ${ }^{30,31}$ (see Supplementary Fig. S2).

Resistance to insects and pests. All the ISH and IGH clones of sugarcane with four standard varieties of cane were evaluated to observe their resistance against major insect pests, namely, the early shoot borer (ESB), top borer (TB), stalk borer (SB), and root borer (RB). All the clones were least susceptible (LS) to ESB and TB $(<15 \%$ and $10 \%$, respectively). Twenty-three clones were found to be LS (infestation index $<2$ ), while one clone, GU 07-3730, was moderately susceptible (MS) to SB (infestation index $=2.1-5.00$ ). In case of the RB, 22 clones were LS $(<15 \%)$ and two clones were MS (15.1-30\%) to the RB (Table 4).

Resistance to red rot. The resistance of ISHs and IGHs to red rot were recorded using mixed inocula of two virulent races of $C$. falcatum (CF08 and CF09) prevalent in subtropical India. Out of seventeen ISHs screened, three clones exhibited resistance (R), nine were moderately resistant (MR), two were moderately susceptible (MS), and three were susceptible (S) to this disease (Table 4). The ISH clones 99-81, 99-132, 99-438, and 99-488 


\begin{tabular}{|c|c|c|c|c|c|c|c|c|}
\hline S.no & Clones & SCW (kg) & CB\% & JB\% & NMC/ha & TDM\% & Fibre \% & FB (t/ha) \\
\hline 1 & GU 94-410 & 1.58 & 12.02 & 18.53 & $59,279.18$ & 29.49 & 17.78 & 108.17 \\
\hline 2 & $99-81$ & 1.11 & 8.19 & 17.05 & $83,813.11$ & 30.17 & 16.93 & 103.9 \\
\hline 3 & $99-132$ & 0.82 & 10.19 & 18 & $78,282.83$ & 29.26 & 16.19 & 92.62 \\
\hline 4 & $99-438$ & 1.28 & 8.16 & 17.6 & $76,941.88$ & 28.8 & 12.30 & 120.18 \\
\hline 5 & $99-488$ & 0.9 & 8.89 & 18.7 & $78,787.88$ & 31.83 & 18.02 & 104.19 \\
\hline 6 & $99-489$ & 1.1 & 7.82 & 18.4 & $96,459.75$ & 23.77 & 16.07 & 118.15 \\
\hline 7 & KGS 2004-13 & 1.24 & 8.72 & 17.06 & $79,165.96$ & 28.83 & 19.77 & 140.27 \\
\hline 8 & KGS 2004-48 & 2.25 & 10.48 & 18.63 & $70,664.79$ & 20.97 & 14.36 & 157.46 \\
\hline 9 & KGS 2004-60 & 1.09 & 8.97 & 18.55 & $81,273.24$ & 35.8 & 13.27 & 121.2 \\
\hline 10 & KGS 2004-72 & 1.16 & 10.14 & 18.8 & $52,273.94$ & 30.32 & 18.15 & 84.7 \\
\hline 11 & $2004-90$ & 0.63 & 6.89 & 17.65 & $87,879.12$ & 29.55 & 16.82 & 80.65 \\
\hline 12 & KGS 2004-186 & 1.74 & 10.65 & 18.38 & $55,560.03$ & 27.79 & 17.66 & 141.27 \\
\hline 13 & GU 07-3704 & 0.85 & 4.65 & 13.35 & $138,172.05$ & 22.78 & 14.18 & 165.96 \\
\hline 14 & GU 07-3730 & 0.43 & 5.98 & 17.3 & $124,982.26$ & 40.42 & 18.67 & 85.86 \\
\hline 15 & GU 07-3764 & 0.91 & 7.46 & 18.45 & $102,525.2$ & 32.53 & 16.57 & 101.69 \\
\hline 16 & GU 07-3784 & 0.65 & 5.51 & 16.9 & $120,212.02$ & 37.35 & 17.83 & 95.46 \\
\hline 17 & GU 07-3849 & 0.87 & 4.94 & 15.41 & $158,593.01$ & 28.34 & 17.28 & 138.52 \\
\hline 18 & GU 98-1395 & 1.09 & 10.53 & 17.35 & $62,622.15$ & 29.71 & 17.25 & 85.16 \\
\hline 19 & KGS 99-100 & 1.39 & 7.89 & 16.8 & $90,326.65$ & 24.11 & 16.85 & 163.99 \\
\hline 20 & KGS 99-104 & 1.14 & 9.52 & 18.15 & $60,479.55$ & 29.98 & 17.84 & 79.68 \\
\hline 21 & KGS 99-109 & 0.78 & 8.16 & 16.46 & $106,565.66$ & 28.18 & 19.68 & 97 \\
\hline 22 & GU $04-431$ & 1.18 & 7.97 & 16.6 & $52,759.38$ & 26.9 & 16.84 & 74.94 \\
\hline 23 & GU $04-432$ & 1.99 & 9.87 & 16.53 & $59,854.42$ & 19.78 & 21.15 & 125.47 \\
\hline 24 & Co 0238 & 1.49 & 11.71 & 20.25 & $80,303.54$ & 24.85 & 13.05 & 118.82 \\
\hline 25 & CoJ 64 & 1.34 & 8.9 & 18.88 & $55,176.72$ & 26.01 & 13.51 & 69.57 \\
\hline 26 & $\operatorname{CoS} 767$ & 1.17 & 9.89 & 18.65 & $71,111.11$ & 28.18 & 15.84 & 94.43 \\
\hline 27 & $\operatorname{CoS} 8436$ & 1.24 & 10.56 & 19.03 & $70,110.45$ & 23.24 & 15.1 & 103.62 \\
\hline \multirow[t]{8}{*}{28} & $1148-54-242-2$ & 1.15 & 8.69 & 16.85 & $112,121.21$ & 25.22 & 13.77 & 135.65 \\
\hline & Mean of ISH & 1.09 & 8.22 & 17.57 & $90,874.49$ & 29.88 & 16.58 & 115.31 \\
\hline & Mean of IGH & 1.26 & 8.99 & 16.98 & $72,101.3$ & 26.44 & 18.27 & 104.37 \\
\hline & Mean of Comm. vars & 1.28 & 9.95 & 18.73 & $77,764.61$ & 25.5 & 14.25 & 104.25 \\
\hline & Mean of the experiment & 1.16 & 8.69 & 17.65 & $84,510.61$ & 28.36 & 16.45 & 111.02 \\
\hline & Year & 0.03 & 0.234 & 0.34 & $72,101.3$ & 0.85 & 0.48 & 2.1 \\
\hline & Var & 0.12 & 0.875 & 1.28 & $13,101.2$ & 3.19 & 1.81 & 8.016 \\
\hline & Year $\times$ Var & 0.17 & 1.237 & 1.8 & 18,528 & 4.51 & 2.56 & 11.33 \\
\hline
\end{tabular}

Table 3. Cane growth and quality traits with biomass-contributing traits of ISHs, IGHs, and commercial hybrids of sugarcane during Y1-Year 1 (2013-14) and Y2-Year 2 (2014-15). SCW single cane weight, CB brix \% in cane, $J B$ juice brix \%, NMC number of millable canes, $T D M$ total dry matter, $F B$ fresh biomass $\left(\mathrm{t} / \mathrm{ha}^{-1}\right)$, Comm. vars commercial varieties.

derived from population improved officinarum (PIO) clones, and the ISH clones KGS 2004-13, KGS 2004-48, KGS 2004-60 and KGS 2004-72, derived from S. barberi and S. sinense were rated as resistant. In addition, two ISH clones (GU 07-3764 and GU 07-3849) derived from S. officinarum and S. spontaneum backgrounds were rated resistant to red rot. All the six IGHs were either resistant or moderately resistant to red rot. Out of these, four IGHs, namely, GU98-1395, KGS 99-100, KGS 99-104, and KGS 99-109 were derived from commercial cane crossed with E. arundinaceus and two IGHs-GU04-431 and GU 04-432-were derived from S. robustum and E. arundinaceus.

Cluster analysis. Two-way cluster analysis separated the ISH and IGH clones into two major groups based on their traits (Fig. 2). Group A contains 18 hybrid clones, of which 10 are ISHs (GU 09-410, 99-438, 99-488, 99-489, 99-81, GU 07-3704, GU 07-3730, GU07-3764, GU07-3784, and GU 07-3849) derived from S. officinarum, S. spontaneum, and S. robustum backgrounds. Four of the ISHs (KGS 2004-13, KGS 2004-186, KGS 2004-48, and KGS2004-60) were derived from S. barberi and S. sinense backgrounds. One hybrid was a selfed progeny of cultivar Co 1148. In addition, three hybrids (KGS 99-100, KGS 99-109, and GU04-432) were derived from the intergeneric background of $E$. arundinaceus with commercial cane.

Group B contains ten hybrids of diverse origins. This group is sub-divided into two subgroups $\left(B_{1}\right.$ and $\left.B_{2}\right)$ representing eight and two hybrids, respectively. Subgroup $\mathrm{B}_{1}$ contains two hybrids from the $S$. barberi and $S$. sinense backgrounds and two hybrids from the intergeneric background of $E$. arundinaceus. Subgroup $\mathrm{B}_{2}$ contains 


\begin{tabular}{|c|c|c|c|c|c|c|}
\hline \multirow[b]{2}{*}{ S. No. } & \multirow[b]{2}{*}{ Clone name } & \multirow[b]{2}{*}{ Red rot reaction } & \multicolumn{3}{|l|}{ Incidence (\%) } & \multirow{2}{*}{$\begin{array}{l}\text { Infestation index } \\
\text { Stalk borer }\end{array}$} \\
\hline & & & Early shoot borer & Top borer & Root borer & \\
\hline 1 & GU 092-410 & S & 5.2 & 4.2 & 11.2 & 1.2 \\
\hline 2 & 99-81 & $\mathrm{R}$ & 2.1 & 6.2 & 8.4 & 1.5 \\
\hline 3 & $99-132$ & $\mathrm{R}$ & 3.5 & 4.5 & 8.6 & 1.1 \\
\hline 4 & 99-438 & $\mathrm{R}$ & 2.3 & 2.5 & 7.4 & 0.9 \\
\hline 5 & 99-488 & $\mathrm{R}$ & 8.2 & 6.1 & 10.0 & 1.3 \\
\hline 6 & $99-489$ & MR & 1.6 & 2.0 & 3.1 & 1.4 \\
\hline 7 & KGS 2004-13 & $\mathrm{R}$ & 4.1 & 5.4 & 7.0 & 1.5 \\
\hline 8 & KGS 2004-48 & $\mathrm{R}$ & 2.1 & 5.2 & 2.1 & 1.3 \\
\hline 9 & KGS 2004-60 & $\mathrm{R}$ & 1.0 & 0 & 6.1 & 1.2 \\
\hline 10 & KGS 2004-72 & $\mathrm{R}$ & 7.1 & 4.5 & 9.1 & 1.1 \\
\hline 11 & KGS 2004-90 & MS & 5.6 & 6.1 & 12.0 & 1.0 \\
\hline 12 & KGS 2004-186 & $\mathrm{R}$ & 6.4 & 5.9 & 16.9 & 1.7 \\
\hline 13 & GU 07-3704 & HS & 2.2 & 7.1 & 2.0 & 1.2 \\
\hline 14 & GU 07-3730 & MS & 6.3 & 3.4 & 4.8 & 2.9 \\
\hline 15 & GU 07-3764 & MR & 4.1 & 4.6 & 7.1 & 1.0 \\
\hline 16 & GU 07-3784 & HS & 9.2 & 8.1 & 2.1 & 1.6 \\
\hline 17 & GU 07-3849 & MR & 7.5 & 2.1 & 4.1 & 1.7 \\
\hline 18 & GU 98-1395 & MR & 1.1 & 1.8 & 15.2 & 2.1 \\
\hline 19 & KGS 99-100 & MR & 2.4 & 4.1 & 4.1 & 1.3 \\
\hline 20 & KGS 99-104 & MR & 6.2 & 6.9 & 6.1 & 1.5 \\
\hline 21 & KGS 99-109 & MR & 1.7 & 6.1 & 7.5 & 1.2 \\
\hline 22 & GU 04-431 & $\mathrm{R}$ & 5.5 & 7.1 & 6.2 & 1.8 \\
\hline 23 & GU 04-432 & MR & 5.9 & 6.1 & 3.5 & 1.2 \\
\hline 24 & Co 0238 & MR & 1.4 & 7.4 & 7.1 & 1.9 \\
\hline 25 & CoJ 64 & S & 2.5 & 6.9 & 8.1 & 1.6 \\
\hline 26 & $\operatorname{CoS} 767$ & MS & 7.4 & 6.1 & 7.1 & 1.2 \\
\hline 27 & $\operatorname{CoS} 8436$ & MS & 2.1 & 7.0 & 6.1 & 1.1 \\
\hline 28 & 1148-S4-242-2 & $\mathrm{R}$ & 7.5 & 3.1 & 8.1 & 1.0 \\
\hline
\end{tabular}

Table 4. Evaluation of ISH/IGH clones for red rot and insect-pests.

commercial hybrids of sugarcane, and subgroup $\mathrm{B}_{1}$ contains one hybrid from S. officinarum, S. spontaneum, and S. robustum backgrounds.

\section{Discussion}

The genetic variation found in Saccharum germplasm may play a very significant role in improving sugarcane for biomass production through breeding and biotechnological approaches. Sugarcane intergeneric and interspecific species like Miscanthus, Erianthus, S. officinarum, and S. spontaneum have a lot of allelic diversity and can be exploited further for improving sugarcane biomass yield ${ }^{17,32,33}$. It was possible to develop high dry biomass hybrid clones when the existing commercial cultivars are combined with high biomass type clone ${ }^{22,34,35}$.

Miocque (1999) ${ }^{34}$, who investigated sugarcane growth and biomass for ten crops in Sao Paulo State (Brazil) reports that the highest biomass accumulation occurs when sugarcane has a longer growth period. Further, the potential for crude energy production of sugarcane clones can be enhanced by using fibre-rich species. One of the important findings of this study is that the early generation hybrids of $S$. spontaneum $\left(\mathrm{F}_{1}\right.$ and $\left.\mathrm{BC}_{1}\right)$ and $E$. arundinaceus $\left(\mathrm{F}_{1}\right)$ had higher biomass yields than the later generation clones. This indicates a limited variation in modern cultivars (commercial canes) and necessitates the utilization of wild relatives in improving biomass in sugarcane (Table 3).

Two-way analysis broadly separated the accessions based on trait variation. Group A contains sugarcane hybrids with higher single cane weights, juice brix percentages, and numbers of stalks. This group contains mostly commercial cultivars and other hybrids of diverse origin.

The commercial cultivars Co 0238, CoJ 64, and the interspecific hybrids KGS 2004-48, KGS 2004-186, KGS 2004-60, and GU07-3764 can be used as donors for improving quality traits in sugarcane. The interspecific hybrids GU 07-3847, GU 07-3704, GU 07-3730, and GU 07-3784 can be used further as donor parents for improving yield traits. Group B had higher fresh biomass, total dry matter percentages, and dry biomass-related traits. The IGH KGS 99-100 and ISHs GU 07-3704, KGS 2004-13, KGS 2004-186, KGS 2004-60 and 99-489 can be used as good sources for high biomass producing hybrids for the Indian subtropics. The clustering of trait variations among the ISHs and IGHs can allow breeders to choose different traits from the different clusters for crossing programs. It is also indicated that these potential performers may be considered as candidate donors for further exploiting traits variation for genetic improvement of the sugarcane. 


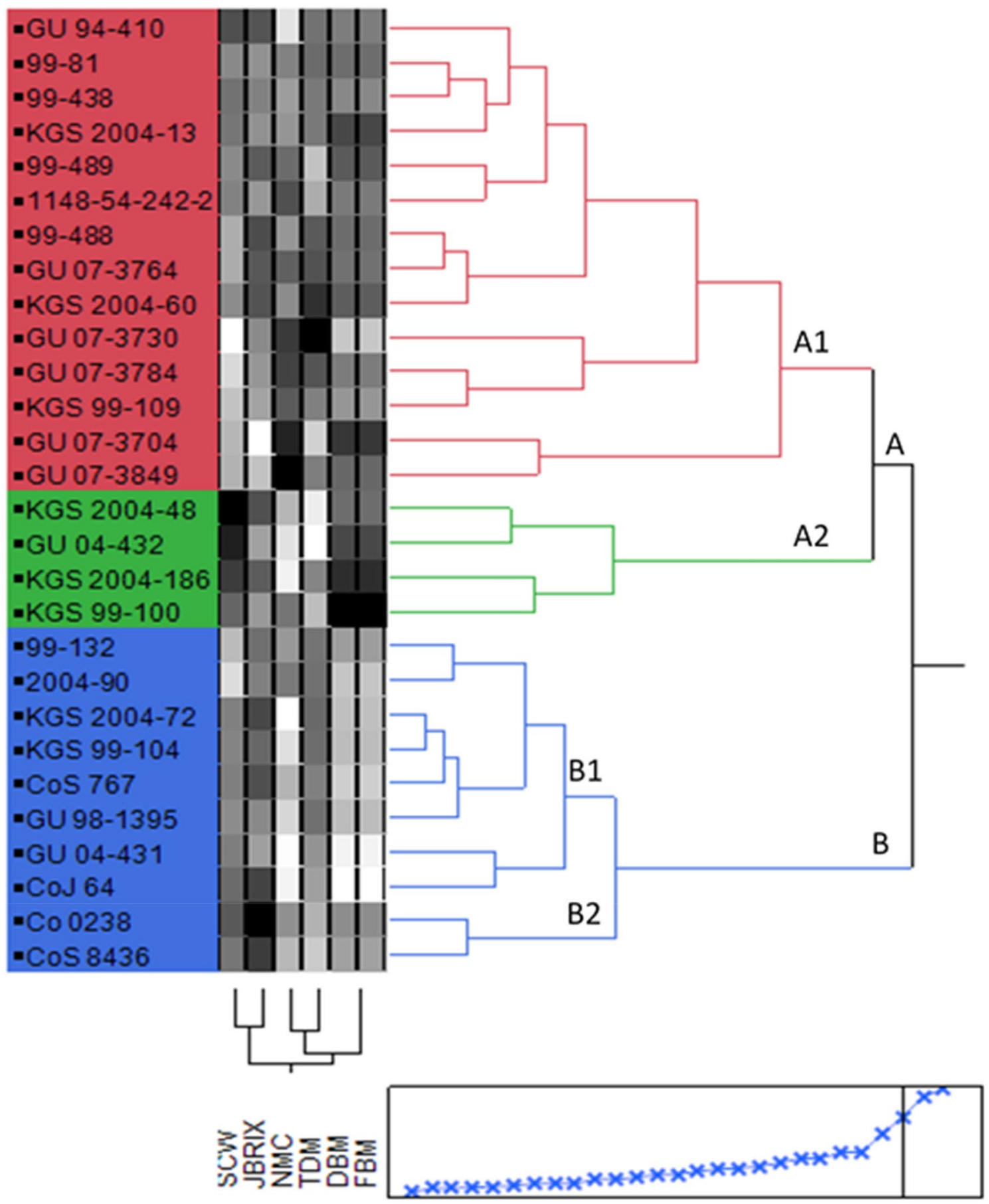

Figure 2. Two-way hierarchical clustering of 28 sugarcane hybrids clones. SCW single cane weight, JBRIX juice brix, $N M C$ number of millable canes, $T D M$ total dry matter, $D B M$ dry biomass matter, $F B$ fresh biomass matter.

Since trait improvement in sugarcane through marker assisted selection (MAS) and genomic selection at the molecular level is difficult due to its genomic complexity (large genome size and high polyploidy level) ${ }^{36-38}$, efforts were made in this study to introgress genes for improvement of biomass yield from allied genera and other species of Saccharum. Out of 28 hybrid clones that were evaluated in this study, five clones of ISHs-2004-186, GU 07-3704, KGS 2004-13, KGS 2004-60 and 99-489-showed significantly higher dry biomass yields as compared to the population mean indicating their superiority over the existing commercial cultivars. Since the ISHs have $S$. officinarum, S. spontaneum, S. robustum, S. barberi, or S. sinense as one of the parents in their backgrounds, it is likely that these species have contributed traits that have significantly improved morphology, good ratooning, and tolerance to various biotic and abiotic stresses ${ }^{39,40}$. In addition, since these species are ecologically well adapted to subtropical Indian conditions, their hybrid clones can grow well even in marginal lands. ISHs-GU 07-3704, GU 07-3730, GU 07-3764, GU 07-3784, and GU 07-3849—-showed significantly superior winter sprouting over 
the best standard CoS 767 (supplementary Fig. S1), because of these hybrids background contains contribution of the genome from population improved S. officinarum and S. spontaneum. Screening against red rot from the wild germplasm of sugarcane, allows new sources of resistant and red rot resistant can be transferred into cultivated species through interspecific and intergeneric crosses ${ }^{41}$. In the study, ISHs clones-derived from population improved officinarum, S. barberi $\mathrm{x}$ S. sinense and S. officinarum $\times$ S. spontaneum, were reported as resistant against red rot. Among the species, S. spontaneum originated clones have high level of resistance against red $\operatorname{rot}^{42}$, and effectiveness of $S$. spontaneum in sugarcane breeding had been evident since the development of first interspecific hybrid 'Co 205' in sugarcane. IGH clones-derived form E. arundinaceous with commercial cane and $S$. robustum with E. arundinaceous produced resistant clones against red rot. Use of Erianthus spp. as potential source for diversifying the genetic base and red rot resistance in sugarcane ${ }^{43}$. Furthermore, the majority of clones studied were least susceptible for early shoot and root borers due to their wider genetic makeup, hence showed resistance reactions against the major insets prevailing in subtropics.

Our results show that ISH and IGH clones performed well in the field conditions. Sugarcanes, Miscanthus species (Miscanthus giganteus), Erianthus species (E. arundinaceus Retz.), and switchgrass (Panicum virgatum) are known to be efficient biomass accumulators and converters of solar energy into chemical energy ${ }^{11,44}$. These traits were also found in the IGHs KGS 99-100 and GU 04-432, which were significantly better than the best commercial cultivar Co 0238 in producing dry biomass. Similarly, in terms of estimated energy, IGH clone KGS 99-100-a hybrid derivatives of the commercial cane and E. arundinaceous, and clone GU04-432-a hybrid derivatives of $S$. robustum and E. arundinaceous, had significantly higher energy value than the existing commercial varieties (supplementary Fig. S2). Therefore, these hybrids could be good sources for improving biomass and bioenergy traits in popular cultivars of sugarcane. Erianthus spp. due its higher biomass accumulation and calorific value, good ratoon ability and exceptional adaptability to biotic and abiotic stresses, is considered as potential breeding material for use in future sugarcane breeding programs $\mathrm{s}^{45}$. Intergeneric material is powerful tools for widening the genetic base in polyploidy crop breeding. Harvey et al. (1994) ${ }^{46}$ also suggested the use of Miscanthus and Erianthus species for broadening genetic bases in sugarcane breeding programs. Furthermore, the use of ISH and IGH clones in sugarcane hybridization can tap into many relevant genetic variations in the germplasm for better biomass production traits while also broadening the genetic base ${ }^{47}$.

Though biomass improvement in sugarcane can be challenging due to several issues such as the small gene pool in currently available sugarcane cultivars, long breeding periods and selection cycles, poor synchronization and fertility of flowers in parental lines, and genome complexity associated with this ${ }^{48,49}$. Since wild sugarcane species have more genetic variability than domesticated sugarcane cultivars, it makes sense to use ISHs and IGHs clones to improve biomass traits in sugarcane. In addition, breeding efficiencies can be improved by selecting for parental strains with wide genetic backgrounds coupled with introgression of genes for improving biotic and abiotic stress tolerance.

In conclusion, our study shows that the utilization of the Saccharum and Erianthus species in sugarcane breeding programs has the potential for generating clones with enhanced biomass accumulation and yields. The tremendous genetic diversity present in these species could be used as a significant genetic reservoir for improving biomass and bioenergy production traits in commercial canes which have narrow gene pools. Currently, long breeding cycles, non-synchronous flowering, and poor fertility among the desired parents are major bottlenecks for the efficient improvement of sugarcane for biomass contributing traits. These hurdle's can be overcomes by utilizing ISH and IGH clones in sugarcane breeding programs to develop superior clones of high biomass potential and high tolerance for abiotic and biotic stresses. Generated clones with increased biomass and bioenergy traits in this study will be good genetic material for further utilization in sugarcane breeding programs in improving biomass-energy traits. Furthermore, these clones could be grown in lands other than prime agricultural land (thereby avoiding competition for land with food industries) to meet the growing demands for energy.

\section{Methods}

Plant material and experimental site. All experimental were carried out on 28 clones obtained from 17 ISHs and six IGHs (IGH), one inbred, and four commercial sugarcane checks (two early-Co 0238, CoJ 64, and two mid-late- $\operatorname{CoS} 767, \operatorname{CoS} 8436$ checks (Table 1). These clones were evaluated for their biomass production potential and other related traits under subtropical conditions in India. The population-improved S. officinarum (PIO), S. spontaneum (SIP), and S. robustum (PIR) clones used in this study were the product of intra population improvement programs for their respective species.

The experimental site was located at the ICAR-Sugarcane Breeding Institute, Regional Centre, Karnal (Haryana) India $\left(29.1^{\circ}-29.5^{\circ} \mathrm{N}\right.$ and $\left.76.3^{\circ}-77.1^{\circ} \mathrm{E}\right)$, which has a subtropical climate. The location stands at an elevation of $243 \mathrm{~m}$ above mean sea level and receives an average rainfall of $\sim 744 \mathrm{~mm}$ per year. The maximum temperatures here range from $34-45^{\circ} \mathrm{C}$ in summer, and minimum temperatures range from $5-8^{\circ} \mathrm{C}$ in winter. The maximum and minimum temperatures, evaporation rates, relative humidity, and rainfall during 2013-14 and 2014-15 are shown in Fig. 3. The soil in this area ranges from clay-loamy to loam, with a pH range from 8.0-8.5; the site is irrigated from a bore well source.

Experimental design. The experiment was conducted in a randomized block design with three replicates for two years (during 2013-14 and 2014-15 spring seasons). The plots used were $2 \mathrm{~m} \times 6 \mathrm{~m}$ with $0.9 \mathrm{~m}$ spacing in size. Recommended crop production practices were followed for raising the experimental crop. Data on the numbers of millable canes (NMC), brix\% in cane, single cane weight (SCW), dry cane weight (DCW), total dry weight (TDM), and fresh biomass weight (FBW) were recorded for each plot from five randomly tagged canes at a crop age of 10 months. Five canes from each plot were used for estimating the percentage of fibre; a subsample of $250 \mathrm{~g}$ of the shredded canes were crushed in a rapipol machine and oven dried. The fresh weights and dry 


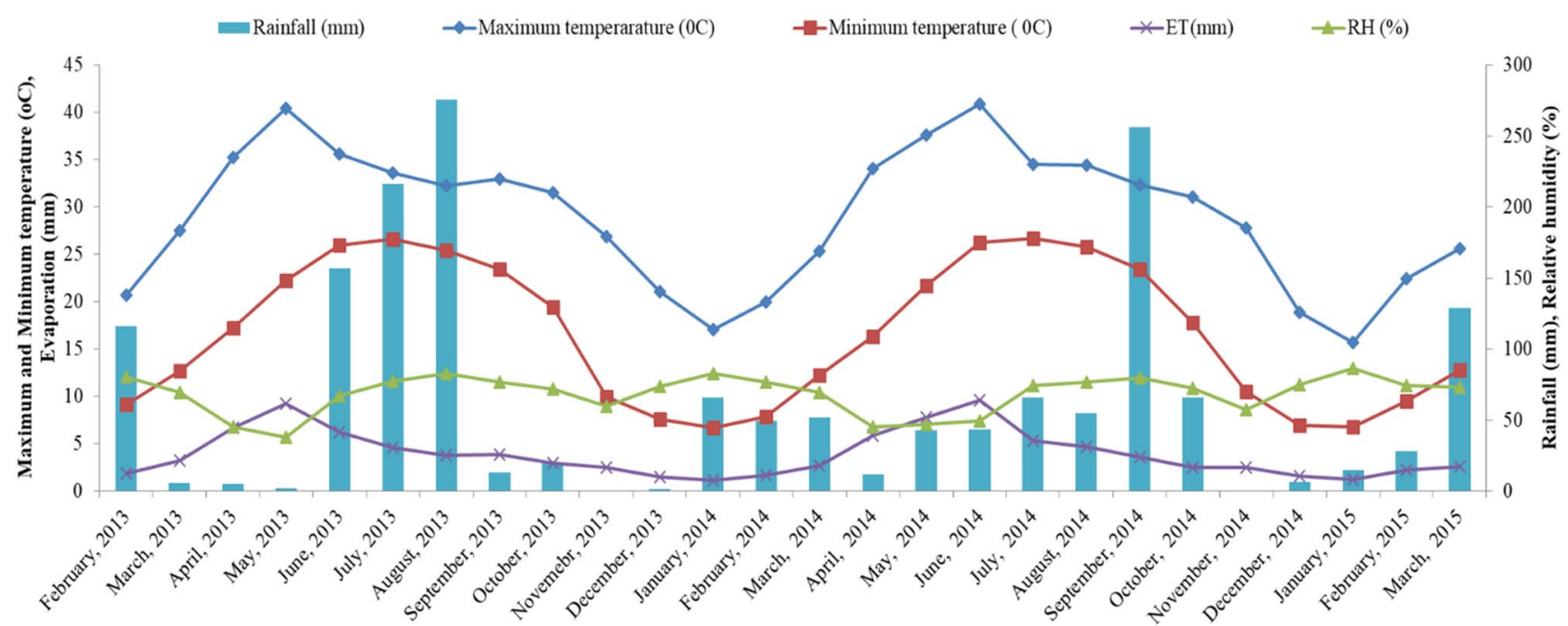

Figure 3. Maximum and minimum temperatures, evaporation rates, and relative humidities of Karnal (Haryana State, India) during the two-year experimentation period.

weights of these samples were recorded. Fibre percentage was estimated using the rapipol extraction method and calculated as per the method explained in Thangavelu and Rao $(1982)^{50}$.

$$
\text { Fibre percent }=\frac{A-B}{C} \times 100
$$

where A is the dry weight of bag + bagasse after drying (g), B is the dry weight of bag alone ( $\mathrm{g}$ ), C is the fresh weight of cane (g).

Juice brix and sucrose percentages were measured from extracted cane juice. Brix percentage in cane and dry cane weight were estimated in the 12th month of the crop, i.e., the harvest stage. Fresh biomass yield was worked out from single cane weight and NMC per plot. CCS percentage at the 12th month was computed as per the method explained in Chen and Chou $(1993)^{51}$. To estimate the dry matter percentage, brix percentage in cane, and dry biomass yield, the following formulae were used.

$$
\mathrm{DM} \text { percent in cane }=\frac{(W S B-W S A) \times \frac{\text { Brix in Juice }}{100}+\frac{W S A \times D M B}{100}}{W S B \times 100}
$$

where WSB is the weight of the sample before crushing (g), WSA is the weight of the sample after crushing i.e. Bagasse $(\mathrm{g})$ and DMB is the dry matter content in bagasse (\%).

$$
\text { Brix percent in cane }=\frac{\text { Juiceextraction } \% \times \text { JuiceBrix } \%}{100}
$$

Fresh biomass yield $\left(\mathrm{t} \mathrm{ha}^{-1}\right)$ was calculated from the number of millable canes/ha $\times$ weight of a single cane (kg) with top attached. Dry biomass yield was calculated in $\mathrm{t} \mathrm{ha}^{-1}$ using following formula described by Mohanraj et al., 2014 $4^{21}$.

$$
\text { Dry Biomass yield }(\mathrm{t} / \mathrm{ha})=\text { Dry matter } \% \times \text { Fresh biomass yield }\left(t / h \mathrm{~h}^{-1}\right)
$$

To identify clones with better ratoonability when harvested during the peak winter period in subtropical climates (i.e., January when temperatures fall below $5{ }^{\circ} \mathrm{C}$ ), sprouting of ISH/IGH clones was quantified. This was done by harvesting the plant crop (half of the row/replicate ( $3 \mathrm{~m}$ row length), and counting the numbers of sprouted clumps per row and recording the average numbers of shoots/sprouted clumps in February; using these, the WSI was calculated ${ }^{52}$. The number of stubbles sprouted per plot and number of shoots formed per clump during winter was counted on the 45th day after ratooning. To ascertain winter sprouting potential of sugarcane clones, a winter sprouting index (WSI) was used as per Bakshi Ram et al. (2017) ${ }^{52}$; the WSI is calculated as follows:

$$
\mathrm{WSI}=\frac{(\% \text { of Sprouted clumps per plot }) \times(\text { number of shoots per clumps })}{100}
$$

Red rot screening. To identify their resistance to red rot, all ISH and IGH clones were screened against the most prevalent and virulent pathotype of red rot (Colletotricum falcatum), namely, Cf 08 and $C f 09$ under field conditions. A mixed inoculum of both races was inoculated into sugarcane plants by plug and nodal methods during the month of September in the 7 -month old crops ${ }^{53}$. 
Energy calculation. The energy content of plant mass mainly depends on its composition; fats and proteins have higher energy contents than simple carbohydrates. Sugarcane is mainly composed of carbohydrates (sugar and lignocellulose) that have an energy content of $(\sim 15.9 \mathrm{MJ} / \mathrm{kg})^{54}$. Energy content was calculated by multiplying the total dry biomass by 15.9 and expressed as Gigajoule/ha/year $(\mathrm{Gj} / \mathrm{ha} /$ year).

Statistical analysis. All data were subjected to analysis of variance (ANOVA) tests. Means, standard deviations, and coefficients of variance for different traits were computed using the statistical package SAS 9.3 software (SAS Institute Inc., Cary, USA). Cluster analysis was performed using the JMP pro 10.0 version to elucidate the differences between IGHs, ISHs, and commercial varieties of sugarcane. Analysis of means (ANOM) was done for comparing energy values and winter sprouting index (WSI) values of the different ISHs, IGHs, and commercial sugarcanes.

\section{Data availability}

The data generated during and/ or analyzed during the current study are available from the corresponding author on reasonable request.

Received: 26 April 2020; Accepted: 28 October 2020

Published online: 09 December 2020

\section{References}

1. Fawzy, S., Osman, A. I., Doran, J. \& Rooney, D. W. Strategies for mitigation of climate change: a review. Environ. Chem. Lett. https ://doi.org/10.1007/s10311-020-01059-w (2020).

2. FAO. http://faostat3.fao.org/home/E. (2019).

3. Zhu, X.-G., Long, S. P. \& Ort, D. R. What is the maximum efficiency with which photosynthesis can convert solar energy into biomass?. Curr. Opin. Biotechnol. 19, 153-159 (2008).

4. Singels, A., Smit, M. A., Redshaw, K. A. \& Donaldson, R. A. The effect of crop start date, crop class and cultivar on sugarcane canopy development and radiation interception. F. Crop. Res. 92, 249-260 (2005).

5. Botha, F. C. Energy yield and cost in a sugarcane biomass system. in 31st Annual Australian Society of Sugar Cane Technologists Conference 2009, ASSCT 2009 134-143 (Proceeding of Australian Society Sugarcane Technologists, 2009).

6. Verheye, W. Growth and production of sugarcane. in Soils, Plant Growth and Production (ed. Encyclopedia of Life Support Systems (EOLSS), D. under the A. of the U.) (Eolss Publishers, 2010).

7. Osman, A. I. Mass spectrometry study of lignocellulosic biomass combustion and pyrolysis with NOx removal. Renew. Energy 146, 484-496 (2020).

8. van Vuuren, D. P. et al. The role of negative CO2 emissions for reaching $2{ }^{\circ} \mathrm{C}-214$ insights from integrated assessment modelling. Clim. Change 118, 15-27 (2013).

9. Nichol,J.E. Spatiotemporal variation of soil carbon in federal capital territory-Abuja, Nigeria. Eur. J. Sci. Res. 42, 220-231 (2010).

10. Biggs, J.S., Thorburn, P.J., Crimp, S., Masters, B. A. S. Interactions between climate change and sugarcane management systems for improving water quality leaving farms in the Mackay Whitsunday region, Australia. Agric. Ecosyst. Environ. (2012).

11. Furtado, A. et al. Modifying plants for biofuel and biomaterial production. Plant Biotechnol. J. 12, 1246-1258 (2014).

12. Hall, D.O., Rosillo-Calle, F., Williams, R.H., Woods, J. Biomass for energy: Supply prospects. in Renewables for Fuels and Electricity (ed. B.J. Johansson, H. Kelly, A. K. N. R., R. H. W.) (Island Press, 1993).

13. Pandey, A., Soccol, C. R., Nigam, P. \& Soccol, V. T. Biotechnological potential of agro-industrial residues. I: Sugarcane bagasse. Bioresour. Technol. 74, 69-80 (2000).

14. Manfredi, A. P. et al. Integral process assessment of sugarcane agricultural crop residues conversion to ethanol. Bioresour. Technol. 260, 241-247 (2018).

15. Pereira, S., Maehara, L., Machado, C. \& Farinas, C. 2 G ethanol from the whole sugarcane lignocellulosic biomass. Biotechnol. Biofuels 8, 44 (2015).

16. Hailing, P. ; S.-B. P. Overview of lignocellulosic feedstock conversion into ethanol - focus on sugarcane bagasse. Int. Sugar J. 110, 191-194 (2008).

17. Hoang, N. V., Furtado, A., Botha, F. C., Simmons, B. A. \& Henry, R. J. Potential for genetic improvement of sugarcane as a source of biomass for biofuels. Front. Bioeng. Biotechnol. 3 (2015).

18. Goldemberg, J., Coelho, S. T. \& Guardabassi, P. The sustainability of ethanol production from sugarcane. Energy Policy 36, 20862097 (2008).

19. Leal, M. R. L. V. et al. Sugarcane straw availability, quality, recovery and energy use: A literature review. Biomass Bioenerg. 53, 11-19 (2013).

20. Borjesson, P., Gustavsson, L., Christersson, L. \& Linder, S. Future production and utilisation of biomass in Sweden. Biomass Bioenergy 13, 399-412 (1997).

21. Mohanraj, K. \& Nair, N. V. Biomass potential of novel interspecific hybrids involving improved clones of Saccharum. Ind. Crops Prod. 53, 128-132 (2014).

22. Wagih, M. E., Ala, A. \& Musa, Y. biomass analysis and selection of sugarcane genotypes for drought tolerance. Sugar Tech. 5, 257-263 (2003).

23. Kandel, R., Yang, X., Song, J. \& Wang, J. Potentials, challenges, and genetic and genomic resources for sugarcane biomass improvement. Front. Plant Sci. 9 (2018).

24. Wang, L.-P. et al. Evaluation of sugarcane $\times$ progeny for biomass composition and yield components. Crop Sci. 48, 951-961 (2008).

25. Aitken, K. M. M. Diversity analysis. in Genetics, Genomics and Breeding of Sugarcane. (Science Publishers, 2010).

26. Govindaraj, P. \& N. N. V. Energy Cane Option for Sugar Complex: Augmenting Feed Stock Supply to Cogeneration Plants. (SBI, 2014).

27. Legendre, B. L. \& Burner, D. M. Biomass production of sugarcane cultivars and early-generation hybrids. Biomass Bioenerg. 8, 55-61 (1995).

28. Long, S. P., Zhu, X.-G., Naidu, S. L. \& Ort, D. R. Can improvement in photosynthesis increase crop yields?. Plant Cell Environ. 29, 315-330 (2006).

29. Olweny, C., Abayo, G., Dida, M. \& Okori, P. Screening of sweet sorghum (Sorghum bicolor (L.) Moench) varieties for sugar and biomass production. Sugar Tech 15, 258-262 (2013).

30. Carvalho-Netto, O. V. et al. The potential of the energy cane as the main biomass crop for the cellulosic industry. Chem. Biol. Technol. Agric. 1, 1-8 (2014).

31. de Siqueira Ferreira, S., Nishiyama, M. Y., Paterson, A. H. \& Souza, G. M. Biofuel and energy crops: high-yield Saccharinae take center stage in the post-genomics era. Genome Biol. 14, 210 (2013). 
32. Burner, D. M., Tew, T. L., Harvey, J. J. \& Belesky, D. P. Dry matter partitioning and quality of Miscanthus, Panicum, and Saccharum genotypes in Arkansas, USA. Biomass Bioenerg. 33, 610-619 (2009).

33. Edwards, D., Batley, J. \& Snowdon, R. J. Accessing complex crop genomes with next-generation sequencing. Theor. Appl. Genet. 126, 1-11 (2013).

34. Landell, M. G. de A. et al. Residual biomass potential of commercial and pre-commercial sugarcane cultivars. Sci. Agric. 70, 299-304 (2013).

35. Naidu, K. M. Potential Yield in Sugarcane and Its Realization Through Varietal Improvement. (Sugarcane Breeding Institute, 1989).

36. Jannoo, N. et al. Molecular investigation of the genetic base of sugarcane cultivars. Theor. Appl. Genet. 99, 171-184 (1999).

37. Sreenivasan, T. V., Ahloowalia, B. S. \& Heinz, D. J. Cytogenetics in Sugarcane Improvement Through Breeding. https://doi.org/10.1016/ B978-0-444-42769-4.50010-2 (Elsevier, 1987).

38. Lu, Y. H. et al. Relationships among ancestral species of sugarcane revealed with RFLP using single copy maize nuclear probes. Euphytica 78, 7-18 (1994).

39. Tew, T. L. \& Cobill, R. M. Genetic improvement of sugarcane (Saccharum spp.) as an energy crop. in Genetic Improvement of Bioenergy Crops 273-294 https://doi.org/10.1007/978-0-387-70805-8_9 (2008).

40. Govindaraj, P., Amalraj, V. A., Mohanraj, K. \& Nair, N. V. Collection, characterization and phenotypic diversity of Saccharum spontaneum L. from arid and semi arid zones of northwestern India. Sugar Tech 16, 36-43 (2014).

41. Babu, C., Koodalingam, K., Natarajan, U., Shanthi, R. \& Govindaraj, P. Genetic enhancement of sugarcane (Saccharum sp. hybrids) for resistance to red rot disease and economic traits. J. Agric. Sci. 4, 97 (2010).

42. Alexander, K. C., Rao, M. M., Mohanraj, D. \& Prakasam, N. P. P. Prakasam NPP Sources of resistance to red rot (Glomerella tucumanensis Arx \& Muller) and smut (Ustilago scitaminea Syd.) in different species of Saccharum. Sugar Cane 6, 10-12 (1990).

43. Mohanraj, K. S. A. \& P.A. Broadening the genetic base of sugarcane: introgression of red rot resistance from the wild relative Erianthus procerus. in Proceedings of XII International Society of Sugar Cane Technologists Pathology Workshop, September 03-07, 2018, Vol 18, ICAR-SBI, Coimbatore (2018).

44. Fedenko, J. R. et al. Biomass production and composition of perennial grasses grown for bioenergy in a subtropical climate across Florida, USA. BioEnergy Res. 6, 1082-1093 (2013).

45. Singh, M. P. et al. Mineral composition and removal of six perennial grasses grown for bioenergy. Agron. J. 107, 466-474 (2015).

46. Harvey, M. H. B. \& B. F. Use of Polymerase Chain Reaction (PCR) and Random Amplification of Polymorphic DNAs (RAPDs) for the Determination of Genetic Distances Between 21 Sugarcane Varieties. (Proceedings of the South African Sugar Technologists Association, Citeseer, 1994).

47. Todd, J. et al. Phenotypic characterization of the Miami World Collection of sugarcane (Saccharum spp.) and related grasses for selecting a representative core. Genet. Resour. Crop Evol. 61, 1581-1596 (2014).

48. Lakshmanan, P. et al. Sugarcane biotechnology: The challenges and opportunities. Vitr. Cell. Dev. Biol. Plant 41, 345-363 (2005).

49. Manickavasagam, M. et al. Agrobacterium-mediated genetic transformation and development of herbicide-resistant sugarcane (Saccharum species hybrids) using axillary buds. Plant Cell Rep. 23, 134-143 (2004).

50. Thangavelu, S. C. R. K. Comparison of Rapi pol extractor and Cutex cane shredder methods for direct determination of fibre in Saccharum clones. Proc. Ann. Conv. Sugar Tech. Assoc. India 46, 15-21 (1982).

51. Chen, J. C. P. \& C. C. C. Cane Sugar Handbook. (Wiley, 1993).

52. Bakshi, R. et al. Winter sprouting index of sugarcane genotypes is a measure of winter ratooning ability. Int. J. Dev. Res. 7, 15385-15391 (2017).

53. Srinivasan, K. V. B. N. R. Red rot of sugarcane - Criteria for grading resistance. J. Indian Bio Soc. 40, 566-577 (1961).

54. Waclawovsky, A. J., Sato, P. M., Lembke, C. G., Moore, P. H. \& Souza, G. M. Sugarcane for bioenergy production: An assessment of yield and regulation of sucrose content. Plant Biotechnol. J. 8, 263-276 (2010).

\section{Acknowledgements}

We thank the Director, ICAR-Sugarcane Breeding Institute, Coimbatore, India for facilitating these experiments. We also acknowledge the competent assistance of field and technical staff from ICAR-SBIRC, Karnal in conducting the trials, collecting samples, and analysing the data for this work.

\section{Author contributions}

Conceptualization of research (B.R., R.K., M.R.M.); Designing of the experiments (R.K., M.R.M., B.R.); Execution of field/lab experiments and data collection (M.R.M., M.L.C., B.P., S.K.P., R.K.); Analysis of data and interpretation (M.R.M., A.K., K.M.R.); Preparation of manuscript (M.R.M., B.R., N.K.); All authors have reviewed the manuscript.

\section{Competing interests}

The authors declare that the research was conducted in the absence of any commercial or financial relationships that could be construed as a potential conflict of interest.

\section{Additional information}

Supplementary information is available for this paper at https://doi.org/10.1038/s41598-020-78329-8.

Correspondence and requests for materials should be addressed to M.R.M.

Reprints and permissions information is available at www.nature.com/reprints.

Publisher's note Springer Nature remains neutral with regard to jurisdictional claims in published maps and institutional affiliations. 
(c) (i) Open Access This article is licensed under a Creative Commons Attribution 4.0 International cc) License, which permits use, sharing, adaptation, distribution and reproduction in any medium or format, as long as you give appropriate credit to the original author(s) and the source, provide a link to the Creative Commons licence, and indicate if changes were made. The images or other third party material in this article are included in the article's Creative Commons licence, unless indicated otherwise in a credit line to the material. If material is not included in the article's Creative Commons licence and your intended use is not permitted by statutory regulation or exceeds the permitted use, you will need to obtain permission directly from the copyright holder. To view a copy of this licence, visit http://creativecommons.org/licenses/by/4.0/.

(C) The Author(s) 2020 